\title{
Proactive behaviour towards strength use and deficit improvement, hope and efficacy as predictors of life satisfaction amongst first-year university students
}

\begin{tabular}{|c|c|}
\hline $\begin{array}{l}\text { Authors: } \\
\text { Frederick W. } \\
\text { Elsabe Diede } \\
\text { Karina Moste } \\
\text { Leon T. de Be }\end{array}$ & $\begin{array}{l}\text { tander } \\
\text { icks }^{1} \\
\mathrm{t}^{2} \\
\mathrm{r}^{2}\end{array}$ \\
\hline \multicolumn{2}{|c|}{$\begin{array}{l}\text { Affiliations: } \\
{ }^{1} \text { Optentia Research } \\
\text { Programme, North-West } \\
\text { University, Vaal Triangle } \\
\text { Campus, South Africa }\end{array}$} \\
\hline \multicolumn{2}{|c|}{$\begin{array}{l}{ }^{2} \text { WorkWell Research Unit, } \\
\text { North-West University, } \\
\text { Potchefstroom Campus, } \\
\text { South Africa }\end{array}$} \\
\hline \multicolumn{2}{|c|}{$\begin{array}{l}\text { Correspondence to: } \\
\text { Ederick Stander }\end{array}$} \\
\hline \multicolumn{2}{|c|}{$\begin{array}{l}\text { Email: } \\
\text { 20562594@nwu.ac.za }\end{array}$} \\
\hline \multicolumn{2}{|c|}{$\begin{array}{l}\text { Postal address: } \\
\text { PO Box 1174, Vanderbijlpark } \\
\text { 1900, South Africa }\end{array}$} \\
\hline \multicolumn{2}{|c|}{$\begin{array}{l}\text { Dates: } \\
\text { Received: } 06 \text { Oct. } 2014 \\
\text { Accepted: } 20 \text { Mar. } 2015 \\
\text { Published: } 09 \text { June } 2015\end{array}$} \\
\hline \multicolumn{2}{|c|}{$\begin{array}{l}\text { How to cite this article: } \\
\text { Stander, F.W., Diedericks, E., } \\
\text { Mostert, K., \& De Beer, L.T. } \\
\text { (2015). Proactive behaviour } \\
\text { towards strength use and } \\
\text { deficit improvement, hope } \\
\text { and efficacy as predictors } \\
\text { of life satisfaction amongst } \\
\text { first-year university students. } \\
\text { SA Journal of Industrial } \\
\text { Psychology/SA Tydskrif vir } \\
\text { Bedryfsielkunde, 41(1), Art. } \\
\text { \#1248, } 10 \text { pages. http:// } \\
\text { dx.doi.org/10.4102/sajip. } \\
\text { v41i1.1248 }\end{array}$} \\
\hline \multicolumn{2}{|c|}{$\begin{array}{l}\text { Copyright: } \\
\text { (C) 2015. The Authors. } \\
\text { Licensee: AOSIS } \\
\text { OpenJournals. This work is } \\
\text { licensed under the Creative } \\
\text { Commons Attribution } \\
\text { License. }\end{array}$} \\
\hline 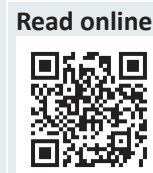 & $\begin{array}{l}\text { Scan this QR } \\
\text { code with your } \\
\text { smart phone or } \\
\text { mobile device } \\
\text { to read online. }\end{array}$ \\
\hline
\end{tabular}

Orientation: The orientation of this study is towards proactive behaviour towards strength use (PBSU) and proactive behaviour towards deficit improvement (PBDI) and their relationship with hope, efficacy and life satisfaction of first-year university students.

Research purpose: To (1) determine whether PBSU and PBDI predict life satisfaction, (2) determine whether PBSU and PBDI predict hope and efficacy and (3) investigate a structural model where hope and efficacy mediate the relationship between PBSU and PBDI and life satisfaction.

Motivation for the study: To validate the use of PBSU and PBDI as resources that will assist first-year university student to attain life satisfaction and to delineate the need for universities to incorporate interventions that promote PBSU and PBDI amongst these students. This supports the case for positive organisational behaviour.

Research design, approach and method: A convenience sample of 566 first-year students from a university in Gauteng was used with a cross-sectional research design. Structural equation modelling was used to establish the validity of the measurement model, fit for the structural model and to test the mediating effects.

Main findings: The results indicated that PBSU was a significant predictor of hope, efficacy and life satisfaction and that PBDI was a significant predictor of hope and efficacy. Hope mediated the relationship between PBSU, PBDI and life satisfaction. Efficacy mediated the relationship between PBSU and life satisfaction.

Practical/managerial implications: Evidence suggests that PBSU was a predictor of life satisfaction. This was not the case with PBDI, which in fact negatively correlated with life satisfaction. Both PBSU and PBDI, however, predicted hope and efficacy. On a practical level this reveals that universities should, in line with positive organisational behaviour, introduce interventions that develop PBSU and PBDI amongst first-year students. It further suggests that, as is postulated by positive psychology, universities should focus more particularly on developing the ability of strength use amongst students, as opposed to deficit improvement.

Contributions/value-add: This research proposes a strong case for the introduction of interventions that promote first-year university students' ability for strength use, in particular, but also for deficit improvement, in line with positive organisational behaviour. Further, it validates for strength use as a stronger value proposition in achieving life satisfaction, supporting the philosophy of positive psychology.

\section{Introduction}

It is well documented that first-year university students often find themselves inadequately prepared for the challenges that face them at tertiary educational level (Mouton, Louw \& Strydom, 2013). In South Africa, this is of particular relevance as various dynamics influence the probability of academic success of first-year intakes (Petersen, Louw \& Dumont, 2009). This poses a unique challenge to the higher educational fraternity as there is increasing pressure to provide access to quality higher education to a larger portion of the country's population (Vandeyar, 2010). These pressures have emerged amidst a process of transformation and change in the higher education landscape and must be navigated cautiously (Le Grange, 2011).

The challenges that first-year university students face are many and varied. Salanova, Schaufeli, Martínez and Bresó (2009) argue that the first year of study at university poses a difficult trial as it can be considered unfamiliar terrain. Students often find that they lack the required resources to effectively deal with the challenges facing them at tertiary educational level (Reeve, Shumaker, 
Yearwood, Crowell \& Riley, 2013). In South Africa, first-year students are the products of a secondary educational system that has undergone significant changes in recent years, including new policy directions and structures (Steenkamp, Baard \& Frick, 2009). Access, funding, and quality of teaching and learning are other stressors that South African first-year students face (Mouton et al., 2013). These stressors inevitably influence the graduation rate of students in South Africa, which stands at only 15\% (Department of Higher Education and Training, 2013).

The array of challenges that students have to deal with in a complex learning environment can potentially influence their levels of life satisfaction, an important component of well-being (Van Zyl \& Rothmann, 2012). Bakker, Albrecht and Leiter (2011) postulate that it is important to investigate factors that influence student well-being as a means of developing interventions that could assist in the development of this part of their lives.

This study will investigate the influence of proactive behaviour towards strength use (PBSU), proactive behaviour towards deficit improvement (PBDI) and two psychological capital constructs (hope and efficacy) on the satisfaction with life levels of first-year students at a South African university.

\section{Proactive behaviour towards strengths use and deficit improvement}

PBSU and PBDI approaches form part of a modern school of thought known as positive psychology. This branch of psychology is focused on ascertaining insight into the potentialities and virtues of individuals (Linley, Joseph, Harrington \& Wood, 2006; Seligman \& Csikszentmihalyi, 2000; Wood, Linley, Maltby, Kashdan \& Hurling, 2011). It supplements the premise of traditional psychology approaches that have been concentrated on rectifying human flaw, abnormality or deficiency (Cravens, Oliver \& Stewart, 2010). Positive psychology is organised around understanding what people are good at, rather than what they may be doing wrong (Compton, 2005).

PBSU can be described as the proactive behaviour that people utilise to accomplish goals (Van Woerkom, Mostert, Els, Rothmann \& Bakker, in press). Moreover, it can be viewed as the inclination of not merely accepting the status quo, but actively capitalising on one's areas of strength, virtue and potentiality, mobilising one's inherent capitals of forte to ensure that development ensues (Van Woerkom et al., in press). Crant (2000) describes this as being crucial in reaching workplace and personal goals. Frese and Fay (2001) label proactive behaviour as essential in dealing with challenges and persevering, regardless of obstacles. PBSU implies pre-emptive behaviour on the part of the individual, such that this person would be positively inclined to make active use of their talents rather than accepting in a passive manner that they do not have control over a set of circumstances
(Botha \& Mostert, 2014). PBDI has been designated as the proactive behaviour that an individual holds to develop their areas of deficit in order to efficiently deal with personal and work-related stressors and accomplish goals (Van Woerkom et al., in press). This behaviour is critical in developing the holistic self, as one must capitalise on one's strengths whilst being equally realistic about one's shortcomings, proactively developing these areas towards becoming a rounded human being (Linley et al., 2006).

\section{Relationship between PBSU, PBDI and satisfaction with life}

Both PBSU and PBDI have been associated with positive personal outcomes. Firstly, PBSU has been associated with meaningful experiences, satisfaction, engagement and pleasure in a working context (Seligman, 2011). Elevated and sustainable well-being has been reported through the use of personal strengths (Peterson \& Seligman, 2004). In a study led by Wood et al. (2011), PBSU predicted positive affect, vitality and lower levels of perceived stress amongst community members from central and northern parts of England. PBDI has been proven as a practically significant (with large effect) predictor of work engagement amongst a sample of sport coaches (Stander \& Mostert, 2013). It is also traditionally linked to the development of people through what is known as the balanced strength-and-deficit-based approach (Kaiser \& White, 2009).

The broaden-and-build model holds that the positive, proactive utilisation of strengths and improvement of deficits will evoke positive emotions that harness thought-action repertoires that create personal resources (Frederickson, 2002). With regard to strengths use amongst university students, Bowers and Lopez (2010) suggest that university students who possessed the capacity to use their personal strengths were able to effectively draw on social support and were well positioned to reach successful outcomes in their tertiary educational career.

Little work exists on the relationship between a balanced strength-and-deficit-based approach and favourable personal outcomes in the context of South African students and much less so amongst specifically first-year students. This study will seek to investigate the relationship between PBSU, PBDI and satisfaction with life, a construct that has been described by Seligman (2011) as one of the very first empirical measures of happiness. Satisfaction with life comprises an individual's cognitive and emotional evaluation over the state of their life at a particular point in time (Diener, 1984). Satisfaction with life is a critical psychological construct in the context of university students as it has been proven to be a predictor of academic performance in a large sample of South African university students (Van Zyl \& Rothmann, 2012). This finding is also supported by Rode et al. (2005), who found a positive relationship between satisfaction with life and academic achievement, as well as between satisfaction with life and positive assessment centre results in a sample of university 
students from the United States. Considering the premise of the broaden-and-build theory and the research outlined above, this paper postulates the following:

Hypothesis 1a: PBSU will predict satisfaction with life (SWL) in a sample of South African first-year university students.

Hypothesis 1b: PBDI will predict satisfaction with life (SWL) in a sample of South African first-year university students.

\section{The relationship between PBSU, PBDI, hope and efficacy}

The use of strengths and the improvement of deficits elicit positive affects which lead to heightened motivation and subsequent better performance (Cropanzano \& Wright, 2001), and can generate subjective well-being that assists in achieving goals (Kaiser \& White, 2009). Psychological capital (PsyCap) has been supported in research as an emerging higher order construct associated with higher performance (Luthans, Avolio, Avey \& Norman, 2007); it draws from Hobfoll's (2002) psychological resource theory and is linked to positive individual outcomes. Psychological capital, together with contextual influences, directs the perception of well-being (Singh \& Mansi, 2009) and can be defined as 'an individual's positive psychological state of development' (Luthans, Youssef \& Avolio, 2007, p. 3). PsyCap comprises four psychological resources, namely (1) being assured enough (self-efficacy) to embrace challenging tasks, (2) being positive (optimism) about achieving current and future success, (3) showing tenacity towards goal achievement and, in pursuit of success, even redirecting paths to goals (hope) when necessary and (4) when encountering adversity or problems, being resilient enough to bounce back (and beyond) in pursuit of success (Luthans et al., 2007).

According to the conservation of resources theory, individuals accrue, preserve and protect those resources they value and that they can apply to accommodate, resist or conquer threats (Hobfoll, Freedy, Lane \& Geller, 1990), which may include the personal resources as contained in PsyCap (hope, efficacy, resilience and optimism). Traumatic events, such as attending university for the first time, consume these resources and might even deplete them, causing individuals to experience stress which may render them potentially inadequate to resolve imminent strains, leading to burnout (Gorgievski \& Hobfoll, 2008), which then results in minimal or no engagement (Chen, Westman \& Eden, 2009; Gorgievski \& Hobfoll, 2008; Xanthopoulou, Bakker, Demerouti \& Schaufeli, 2008).

A fundamental goal of universities is to help build human capital that will eventually become companies' most important (competitive) assets through delivering educated, mature graduates by equipping them with knowledge, skills and competencies that will enable them to excel in the workplace. It is thus imperative to build on students' strengths and positive psychological resources (Luthans et al., 2007). Previous research studies that investigated the relationship between the different psychological constructs that comprise PsyCap and student academic performance have consistently shown either all of the individual constructs or occasionally two of them to be strong predictors of academic success (Chemers, $\mathrm{Hu} \&$ Garcia, 2001; Curry, Snyder, Cook, Ruby \& Rehm, 1997; Martin \& Marsh, 2006; Ruthig, Perry, Hall \& Hladkyj, 2004; Stajkovic \& Luthans, 1998). In this study, efficacy and hope as constructs of PsyCap will be investigated in relation to PBSU and PBDI of first-year university students. These constructs were selected out from the PsyCap literature due to the extensive research done in student contexts on these constructs in particular.

\section{Efficacy}

According to Bandura (1998), an optimistic sense of personal efficacy is a prerequisite for positive well-being, especially in overcoming the great number of obstacles on the road to success. Self-efficacy refers to the individual's own positive belief about their capabilities to organise and mobilise courses of action towards successfully performing a specific task within a certain context (Singh \& Mansi, 2009; Stajkovic \& Luthans, 1998). Bandura (1998) postulates that self-efficacy beliefs impact almost every aspect of an individual's life and therefore an individual's actual behaviour can often be better predicted by the beliefs they have about their competencies than by what they are actually capable of achieving.

A clear distinction can be drawn between the behaviour of individuals who regard themselves as highly efficacious and those who perceive themselves to be inefficacious. Efficacious individuals show PBSU in that they regard difficult tasks as challenges to be mastered, are committed towards goal attainment and show strong perseverance and confidence in the face of adversity, always exerting more effort and dedication towards difficult tasks, recovering quickly from disappointments and acquiring new knowledge and skills to address and improve their shortcomings (deficit improvement). Individuals with low self-efficacy, on the other hand, may regard problems as more severe than they actually are, perhaps even avoiding them, show weak commitment to goals and, in the face of adversity, would focus on their personal failings and negative outcomes and slacken (or halt) their efforts in accomplishing a difficult task (Bandura, 1998; Singh \& Mansi, 2009).

Perceived self-efficacy plays a fundamental role in academic success, through motivation and achievement, enhancing effort and tenacity in academic activities (Zimmerman, 1995). Students' beliefs in their efficacy to control their own learning and to accomplish academic activities govern their ambitions, motivation and academic achievements (Bandura, 1993). PBSU and PBDI are resources that will enable a firstyear student to deal with challenging situations at university, predicting the inherent belief that they could successfully overcome challenges and pressures. A study by Stander and Mostert (2013) found a practically significant correlation 
between PBSU and self-efficacy. On the basis of this literature support, the following hypotheses are proposed:

Hypothesis 2a: PBSU will predict efficacy in a sample of South African first-year university students.

Hypothesis 2b: PBDI will predict efficacy in a sample of South African first-year university students.

\section{Hope}

Hope, according to Snyder, Harris and Anderson (1991), can be defined as a positive emotional state and comprises two components, namely agency (willpower) and pathways (Snyder, 2000). Agency refers to an individual's motivation or willpower to not only start working towards a given goal, but to continue until the task has been accomplished effectively. Motivation towards accomplishing goals becomes especially important when obstacles arise, and willpower becomes evident in positive self-talk comments, such as 'I will not be stopped' or 'I can do this' (Snyder, Lapointe, Crowson \& Early, 1998). Pathways refer to creating the necessary routes to accomplish those goals. Hope has been linked to various positive outcomes in the work context, such as greater organisational success (Adams et al., 2002), financial performance, employee retention and job satisfaction (Peterson \& Luthans, 2003), organisational commitment (Larson \& Luthans, 2006; Youssef \& Luthans, 2007) and happiness at work (Youssef \& Luthans, 2007). In relation to academic success, hope allows students to set prized goals, identify ways of achieving those goals and find the motivation to accomplish them (Snyder, 2002), and it has been linked to positive academic achievements amongst college business students (Luthans, Luthans \& Avey, 2013).

In view of the uncertainty surrounding their new circumstances at university, pre-emptive behaviour such as with PBSU will allow a first-year student to put their talents to active use towards regulating their circumstances, simultaneously generating positive emotional feelings that will instil a will to succeed and guide them to find the way to success. PBDI will allow the first-year to develop their areas of deficit to enable them to deal with any stressors or traumatic events by preserving and protecting their valued personal resources, and will instil in them the necessary hope to identify ways of overcoming any obstacles in pursuit of their goals. PBSU and PBDI are personal resources that, according to Van Den Heuvel, Demerouti, Schaufeli and Bakker (2010), empower individuals to negotiate their challenges and stressors more effectively and enable them to accomplish their goals. On the basis of this literature support, the following hypotheses are proposed:

Hypothesis 3a: PBSU will predict hope in a sample of South African first-year university students.

Hypothesis 3b: PBDI will predict hope in a sample of South African first-year university students.

\section{Hope and efficacy as mediators in the relationship between PBSU, PBDI and satisfaction with life}

A number of studies have been conducted that have effectively postulated PsyCap as a mediator between various variables and positive personal and work-related outcomes. For example, Wang, Chang, Fu and Wang (2012) established that the PsyCap constructs partially mediated the relationship between between work-family conflict and burnout in a large sample $(N=1332)$ of Chinese nurses. In another study, it was proven that PsyCap acted as mediator between leadership and creative performance behaviours within a sample of scientists working in the research and development sector in India (Gupta \& Singh, 2014). Pertaining to the university student context specifically, Riolli, Savicki and Richards (2012) confirm that PsyCap mediates between stress and physical and psychological well-being in a sample of undergraduates from a university in the United States. In the context of that study, PsyCap constructs effectively served as a buffer to reduce the stress experienced by these students as a means of enhancing satisfaction with life and augmenting positive psychological outcomes. It thus serves as a strong theoretical substantiation for the purposes of the current study. The mediating properties of PsyCap can be attributed largely to these personal capitals' ability to equip the individual to more effectively negotiate job demands and, equally so, capitalise on job resources to attain favourable personal and work-related goals (Schaufeli \& Bakker, 2004). It holds true of both the PsyCap constructs investigated in this article, namely hope and efficacy.

The PsyCap construct of hope has been proven to be in a reciprocal relation with engagement in a study amongst university students, led by Siu, Bakker and Jiang (2013). Furthermore, in a study amongst Slovakian university and school students, hope was proven to be a mediator between various personality factors (such as extraversion, conscientiousness and neuroticism) and satisfaction with life (Halama, 2010). Based on these studies and the theoretical description of PsyCap outlined in this article, it is plausible to postulate the following:

Hypothesis 4a: The PsyCap construct of hope will mediate between PBSU and satisfaction with life (SWL) in a sample of South African first-year university students.

Hypothesis 4b: The PsyCap construct of hope will mediate between PBDI and satisfaction with life (SWL) in a sample of South African first-year university students.

With regard to the PsyCap construct of efficacy, research also supports the mediating properties of this variable. In a study amongst student volunteers from a university in Canada, efficacy was proven to be a full mediator between conscientiousness and meaning in life (Lightsey et al., 2014). Based on this, this paper predicts that:

Hypothesis 5a: The PsyCap construct of efficacy will mediate between PBSU and satisfaction with life (SWL) in a sample of South African first-year university students. 


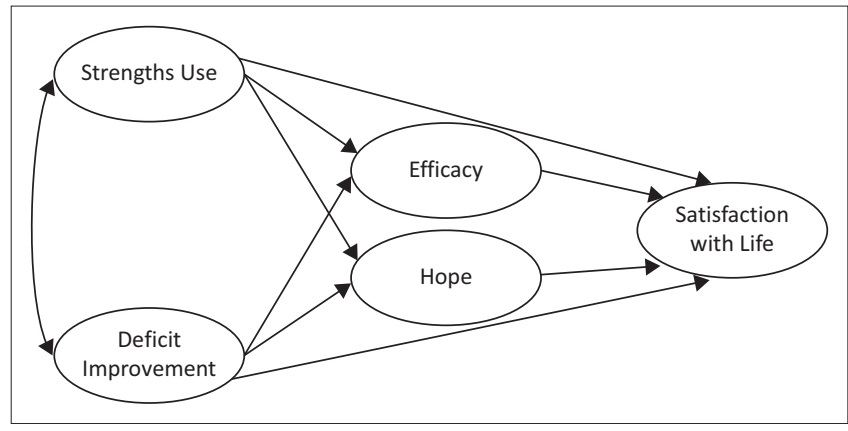

FIGURE 1: The research model.

Hypothesis 5b: The PsyCap construct of efficacy will mediate between PBDI and satisfaction with life (SWL) in a sample of South African first-year university students.

\section{Research method Research design}

A cross-sectional design was used to achieve the objectives of this study (Shaughnessy, Zechmeister \& Zechmeister, 2009). Salkind (2009) refers to a cross-sectional design to be one that measures a number of responses from different participants at one particular point in time.

\section{Research participants and procedure}

The research participants were 566 first-year university students from two faculties (Humanities and Economic Sciences) from a Gauteng-based university. The average age of the sample was $19.76(S D=1.75)$. There were $358(63.3 \%)$ female participants and $192(36.7 \%)$ male participants. The majority were black students $(82.2 \%)$, followed by white students $(13.9 \%)$, Asian students $(1.4 \%)$ and mixed-race students (1.2\%). From the sample, 17.7\% spoke English and Afrikaans, 23.9\% Nguni (isiNdebele, isiZulu, isiXhosa, siSwati), 51.6\% Sotho (Sesotho, Setswana, Sepedi) and 3.7\% Xitsonga or Tsivenda.

The research was conducted during the welcoming and orientation programme at the beginning of the academic year. The university management allowed for designated time slots during the above-mentioned programme and students were organised into their respective faculties and sub-study fields to ensure that the research process could be conducted in a controlled and structured manner. Students were organised in groups of about 100 per time slot and assembled in large lecture halls earmarked for the research project. All groups were thoroughly briefed on the intent, purpose and method of the research project. Students were assured that the research purposes of the project were aimed at gathering useful information, and were guaranteed absolute confidentiality pertaining to their details. They were briefed on the fact that their participation would be anonymous and that participation was absolutely voluntary; they were under no obligation to partake in the research process and could also quit participation during any stage. The researchers working on this project were also available in the designated lecture halls throughout the data collection process, particularly to assist with questions the students could potentially raise. Informed consent was obtained through consent letters distributed to the students. The research was done under the auspices of ethical clearance of a broader research project.

\section{Measuring instruments}

A biographical questionnaire was used to obtain information regarding the biographical characteristics of participants (e.g. age, gender, and home language). Three additional measuring instruments were administered.

\section{Proactive behaviour towards strengths use and deficit improvement.}

Two of the subscales of the Strengths Use and Deficit Improvement Questionnaire (SUDIQ; Van Woerkom et al., in press) were adapted to measure PBSU and PBDI. The SUDIQ in its original format has four subscales; however, only the individual dimensions were relevant to this study. Since the SUDIQ was developed for use in organisational context, items were adapted for the university context. For example, a PBSU item 'I use my strengths at work' was adapted to 'I use my strengths when performing tasks'. An example item of PBDI, 'In my job, I work on my shortcomings', was adapted to read 'During tasks, I work on my shortcomings'. Items are measured on a seven-point Likert scale ranging from 0 (almost never) to 6 (almost always). Reliability of the scales has been proven sufficient through Cronbach's alpha coefficients of 0.93 for PBSU and 0.93 for PBDI (Stander \& Mostert, 2013).

\section{Hope and efficacy}

The two PsyCap constructs of hope and efficacy were measured through the 12-item PsyCap Questionnaire (PCQ 12; Luthans et al., 2007). As in the case of the SUDIQ, items on the PCQ 12 were also adapted to ensure that it would be relevant to the student context. For example, an item for hope, 'I can think of many ways to reach my current work goals', was adapted to 'I can think of many ways to reach my current study goals'. With regard to efficacy, the item 'I feel confident presenting information to a group of colleagues', was adapted to 'I feel confident presenting information to a group of co-students'. The PCQ 12 has been established as a reliable short measure to assess PsyCap, with Cronbach's alpha coefficients of 0.82 (hope) and 0.79 (efficacy) being reported by Luthans et al., (2007). Items are measured on a six-point Likert scale ranging from 1 (strongly disagree) to 6 (strongly agree).

\section{Life satisfaction}

Life satisfaction was measured through the Satisfaction with Life Scale (SWLS; Diener, Emmons, Larsen \& Griffin, 1985). A typical item for the SWLS is 'I am satisfied with my life'. The SWLS utilises a seven-point Likert scale ranging from 1 (strongly disagree) to 7 (strongly agree) and comprises five items. Sufficient reliability for the SWLS has been proven; for example, Alfonso and Allison (1992) established a Cronbach's alpha of 0.89 for the scale. 


\section{Statistical analysis}

Mplus 7.2 (Muthén \& Muthén, 2014) was used to investigate the research hypotheses. Mplus is a powerful statistical software package with the ability to investigate latent variables. In this study no item parcelling, mean or sum score techniques were implemented. The individually observed indicators (items) were therefore used to implement confirmatory factor analysis for each of the latent corresponding variables in one measurement model with maximum likelihood methodology. Regressions paths were then added to the measurement model in accordance with the research hypotheses to constitute a structural model. The following fit statistics were considered: comparative fit index (CFI; acceptable values between 0.90 and 0.99), Tucker-Lewis index (TLI; acceptable values between 0.90 and 0.99), root mean square error of approximation (RMSEA; acceptable values between 0.01 and 0.08 ) and standardised root mean residual (SRMR; acceptable values between 0.01 and 0.08) (Hooper, Coughlan \& Mullen, 2008; Van de Schoot, Lugtig \& Hox, 2012). Given the call for psychologists to move from reporting the problematic alpha coefficient to the betterperforming omega coefficient for reliability, the omega coefficient was calculated in Mplus (cf. Dunn, Baguley \& Brunsden, 2013). For correlations, the level of practical significance $(r)$ is set at 0.30 or above for a medium effect and 0.50 or above for a large effect (Cohen, 1988). To investigate the mediating effects in the model, indirect function was specified in Mplus with a request for 5000 resampling draws in order to focus on the indirect effects in the model (Rucker, Preacher, Tormala \& Petty, 2011). Moreover, mediation results would be described in terms of the contemporary suggestions by Zhao, Lynch and Chen (2010) as either complementary, competing, indirect-only, direct-only or non-mediation effects. Statistical significance $(p)$ is set at 0.05 or above.

\section{Results}

Results revealed that the model fit the data well for both the measurement model: CFI (0.91), TLI, (0.91), RMSEA (0.04) and SRMR (0.05), and the structural model: CFI (0.91), TLI, (0.90), RMSEA (0.04) and SRMR (0.06). Furthermore, the results of measurement invariance testing revealed configural and metric invariance based on gender, which indicates that the factor structure and loadings were similar for both men and women. Based on these results, the following results are presented: the correlation matrix for the latent variables, the structural regressions and the results for mediation testing of indirect effects in the model.

Table 1 presents the correlation matrix for the latent variables in the structural model.

Correlations revealed that PBSU and PBDI are practically significantly correlated with each other to a large degree $(r=0.62)$. PBSU was also practically correlated to SWL $(r=0.35$; medium effect), self-efficacy $(r=0.51$; large effect $)$ and hope ( $r=0.59$; large effect). PBDI was practically
TABLE 1: Correlation matrix for the latent variables.

\begin{tabular}{lccccc}
\hline Variables & PBSU & PBDI & SWL & Efficacy & Hope \\
\hline PBSU & $(0.82)$ & - & - & - & - \\
PBDI & $0.62 * *$ & $(0.83)$ & - & - & - \\
SWL & $0.35^{*}$ & 0.12 & $(0.73)$ & - & - \\
Efficacy & $0.51^{* *}$ & $0.46^{*}$ & 0.29 & $(0.77)$ & - \\
Hope & $0.59 * *$ & $0.56 * *$ & $0.37 *$ & $0.47 *$ & $(0.72)$ \\
\hline
\end{tabular}

Omega reliability coefficients in brackets on the diagonal.

PBDI, individual deficit improvement; PBSU, individual strengths use; SWL, satisfaction

with life.

*, Medium practical significance;

**, Large practical significance

TABLE 2: Standardised estimates for the structural paths.

\begin{tabular}{lcccc}
\hline Regression path & $\boldsymbol{\beta}$ & SE & $\boldsymbol{p}$ & Result \\
\hline PBSU $\rightarrow$ Efficacy & 0.36 & 0.08 & 0.001 & Significant \\
PBSU $\rightarrow$ Hope & 0.41 & 0.07 & 0.001 & Significant \\
PBSU $\rightarrow$ SWL & 0.25 & 0.09 & 0.008 & Significant \\
PBDI $\rightarrow$ Efficacy & 0.25 & 0.08 & 0.001 & Significant \\
PBDI $\rightarrow$ Hope & 0.31 & 0.07 & 0.001 & Significant \\
PBDI $\rightarrow$ SWL & -0.28 & 0.07 & 0.001 & Significant \\
Self-efficacy $\rightarrow$ SWL & 0.16 & 0.08 & 0.032 & Significant \\
Hope $\rightarrow$ SWL & 0.32 & 0.09 & 0.001 & Significant \\
\hline
\end{tabular}

$\beta$, beta coefficient; $p$, two-tailed statistical significance; PBDI, individual deficit improvement; PBSU, individual strengths use; SE, standard error; SWL, satisfaction with life.

significantly correlated with efficacy $(r=0.46$; medium effect) and hope $(r=0.56$; large effect). Furthermore, SWL was also practically correlated to hope with medium effect $(r=0.37)$, but had a borderline medium practical association with efficacy $(r=0.29)$.

Table 2 presents the structural regression results of the structural model from structural equation modelling.

Results from the structural relationships revealed that all of the regressions were significant, which confirmed $H_{1 \mathrm{a}}$ through $H_{3 \mathrm{~b}}$. PBSU had relationships with efficacy $(\beta=0.36)$, hope $(\beta=0.41)$ and SWL $(\beta=0.25)$. Similar results were evident for PBDI which had relationships with efficacy $(\beta=0.25)$ and hope $(\beta=0.31)$. However, PBDI had a negative relationship with SWL $(\beta=-0.28)$. Efficacy had a relationship with SWL $(\beta=0.16)$, but the relationship between hope and SWL was stronger $(\beta=0.32)$.

Concerning the mediation hypotheses, bootstrapping revealed that there were some significant indirect effects. Hope mediated the relationship between PBSU and SWL with an indirect effect of 0.21 (95\% CI [0.10; 0.31], $p=0.003)$, confirming $\mathrm{H}_{4 \mathrm{a}}$ and indicating a complementary mediation (direct effect and indirect in same direction). Hope also mediated the relationship between PBDI and SWL with an indirect effect of $0.12(95 \% \mathrm{CI}[0.03 ; 0.20], p=0.008)$, confirming $H_{4 \mathrm{~b}}$ and indicating a competitive mediation (direct and indirect effects exist, but in opposite directions). Regarding the mediation role of efficacy in the relationship between PBSU $\left(\mathrm{H}_{5 \mathrm{a}}\right)$, PBDI $\left(\mathrm{H}_{5 \mathrm{~b}}\right)$ and SWL, efficacy had a small indirect effect between PBSU and SWL: 0.07 (95\% CI [0.01; 0.12], $p=0.03$ ), but a non-significant indirect effect between PBDI and SWL was evident, which indicated no mediating action for efficacy between PBDI and SWL: 0.05 (95\% CI [0.01; 0.10], 
$p=0.08)$. Thus, $H_{5 \mathrm{a}}$ was confirmed as a complementary mediation, but $H_{5 \mathrm{~b}}$ was rejected, indicating a direct-only nonmediation (direct effect exists, but no indirect effect).

\section{Discussion}

The first positive contribution of this study is the fact that all the adapted measures were proven to be reliable on all dimensions, based on the omega reliability coefficient values. This is applicable to PBSU $(\omega=0.82)$ and PBDI $(\omega=0.83)$ in the case of the SUDIQ, as well as for hope $(\omega=0.72)$ and efficacy $(\omega=0.77)$ in the case of the PCQ 12. This is significant from a practical perspective as it ensures the measures can be used with scientific reliability for further studies specifically relating to these topics within the student and tertiary educational domain. Pertaining to the hypothesised outcomes of this study, PBSU predicted SWL in the sample of first-year students from various disciplines. This holds noteworthy value from the understanding of developmental psychology as it predicts that students who display the ability and self-starting behaviours to proactively utilise their areas of potentiality will be able to effectively navigate the array of challenges presented to them during their first year of study at tertiary educational level. They will be able to achieve satisfaction with life, despite the contests during this crucial time of their academic career. It supports the work of Seligman (2011), who has established that PBSU could potentially facilitate various positive personal outcomes, such as pleasure and meaningful personal work experiences.

The power of PBSU is explained well through the research of Bowers and Lopez (2010), who established that university students who had the capacity for capitalising on their own strengths were better equipped to accumulate and utilise the resources available to them in the realm of their educational career as a means of achieving desired outcomes. From a practical perspective, it is now possible to argue that South African universities must actively seek and promote interventions that aid first-year students in utilising their strengths. Examples of such interventions can include utilising the resources already available through university staff and departments to conduct targeted strength-based development intercessions on an individual level, for example through student counselling services, as well as on the group level, through workshops on strengthbased development, customised and presented at specific levels for specific year groups of students. This will lead to higher levels of satisfaction with life, which in the dominion of South African university students has been proven to be a direct predictor of academic performance (Van Zyl \& Rothmann, 2012). In the context of this research, the fact that PBSU was proven as a predictor of SWL supports the notion of the broaden-and-build theory of Frederickson (2002). From a practical perspective, it is now possible to argue that South African universities must actively seek and promote interventions that aid students in utilising their strengths as a way to facilitate life satisfaction and increase likelihood for academic performance amongst these students.
Interestingly, Hypothesis $1 \mathrm{~b}$, which predicted that PBDI would predict SWL, revealed a negative relationship between these two constructs, meaning, on a practical level, that should a first-year student be focused on proactively and consistently working on their areas of deficit, that student is less likely to experience satisfaction with life. The correlation between PBDI and SWL, albeit negative, proved nearly as strong as the positive correlation between PBSU and SWL. This proved an intriguing part of this research. The only practical explanation one can offer for this phenomenon is the fact that, if an individual is overly focused on their areas of deficit and consistently examines and scrutinises these socalled areas of flaw, that person will be negatively inclined and is likely to experience less general satisfaction with their life. This state of affairs, as proven in this research, is a significant bolster to positive psychology which holds that a focus on potentialities and virtues has a far stronger value proposition than only focusing on what an individual is not good at (Cravens et al., 2010). It does not detract from the notion that balanced development will yield value for holistic development, but highlights the value of strength-based approaches in particular. Although the positive correlation between PBDI and SWL is salvaged by the mediating properties of PsyCap (later discussed in this article), it becomes evident that an in-depth enquiry needs to be made of the difference between PBSU and PBDI in fostering SWL, setting the scene for fruitful further research on this topic, particularly amongst South African university students.

In this study, both PBSU and PBDI were proven as predictors of efficacy, thus confirming Hypothesis 2a and Hypothesis $2 \mathrm{~b}$. Considering the elements of the construct, it becomes clear that self-starting, proactive behaviours of both strength use and deficit improvement will, in theory at the very least, be valuable to achieve greater levels of efficacy. Singh and Mansi (2009) commented that individuals with lower levels of perceived self-efficacy will feel less equipped to deal with challenges and will perceive themselves as being powerless in the navigation of stressors in their personal lives. This is contrary to what is implied through the PBSU and PBDI constructs which both allude to self-starting, proactive behaviours, thus inferring that an individual will take charge of a particular situation or challenge rather than merely stand back, accepting their fate as that of being unable to effectively deal with such a challenge (Van Woerkom et al., in press).

Efficacy is a construct of well-being and should thus be strengthened through PBSU and PBDI when considering the broaden-and-build theory (Frederickson, 2002). Efficacy is directly related to how an individual feels about their ability to deal with a particular challenge. It should thus be reflected by an individual's capacity to proactively seek the use of their psychological faculties to utilise strengths and improve deficits as a means of dealing with trials (Luthans, Avey, Avolio \& Peterson, 2010). As in the case of SWL, efficacy has also been proven to be a significant predictor of academic success amongst students (Bandura, 1993; Zimmerman, 1995); further ensuring that the contribution of 
this study, particularly within the context of South African university students, becomes a practical one. It can now be argued that PBSU and PBDI should be actively encouraged within South African universities and amongst the students, as a way of stimulating these students' perceptions of their ability to overcome challenge and effectively deal with the various stressors associated with the first year of study at an institution of higher learning.

Both PBSU and PBDI were proven as predictors of the PsyCap construct of hope, thereby confirming Hypothesis 3a and Hypothesis $3 b$. It can therefore be argued with scientific merit that, by incorporating PBSU and PBDI interventions within the realm of South African universities, progress may be achieved towards stimulating PsyCap constructs such as hope. This must be understood from the perspective of what hope essentially represents. According to Snyder (2000), hope entails both the will to achieve a particular goal or end result as well as the ability to actively seek and find ways as to achieve the said goal or result. Considering the self-starting nature of both PBSU and PBDI (Van Woerkom et al., in press), it becomes evident that an individual who actively seeks opportunities to utilise their strengths and develop their deficits will more likely experience higher levels of hope. Such a person will feel in better control of their future and will seek pragmatic pathways towards reaching the stated goals, as postulated by Snyder. This supports the hypotheses outlined above.

Hope has directly correlated with a number of positive workrelated outcomes, such as financial performance, employee retention and job satisfaction (Peterson \& Luthans, 2003), as well as organisational commitment (Larson \& Luthans, 2006; Youssef \& Luthans, 2007). It is thus reasonable to argue that hope as a construct will also be a valuable commodity in the arsenal of the first-year South African student towards achieving desired outcomes such as academic performance. In this instance, PBSU and PBDI can serve as valuable personal resources to facilitate higher levels of hope amongst these students.

The following hypotheses of this study predicted that hope would serve as mediator between PBSU and SWL (Hypothesis 4a) and PBDI and SWL (Hypothesis 4b), respectively. This was postulated, based on evidence from two research studies in particular. Firstly, Siu et al., (2013) proved that hope was an effective facilitator of engagement amongst a sample of students from a Hong Kong university. Secondly, Halama (2010) proved that hope could effectively mediate between a variety of personality factors and SWL, particularly in a large sample of Slovakian secondary and tertiary educational students. In the context of this study, it was established that hope served as a mediator between PBSU and SWL (confirming Hypothesis 4a), through complementary mediation with direct effect. It can thus be argued that hope will act in strengthening the relationship between PBSU and SWL, and must be actively promoted in the context of South African universities as a means of ensuring that first-year students experience higher levels of SWL. Hope also proved to be a mediator between PBDI and SWL (confirming Hypothesis $4 b$ ), with indirect effect. This proves the significant value of hope, particularly amongst first-year university students, as a negative correlation was actually established between PBDI and SWL in this study. Thus, although direct paths exist between PBSU and SWL, as well as hope and SWL, hope can serve as a mobilising agent between PBSU and SWL. Further, hope can also translate the capacity for PBDI towards a state of SWL as a mediator.

Within the context of this study, efficacy was established as a mediator between PBSU and SWL, thus confirming Hypothesis 5a, albeit with small indirect effect. This supports the work of Lightsey et al. (2014), who established efficacy as a full mediator between conscientiousness and meaning in life in a sample of Canadian university students. Through this study, it can now be argued that university management teams in South Africa should actively look for and implement interventions to raise students' levels of self-efficacy as a means of strengthening the relationship between PBSU and SWL. This is particularly true of first-year students who are likely to experience various stressors, perhaps even feeling unequipped to effectively deal with the transition from secondary to tertiary educational level (Mouton et al., 2013). Hypothesis $5 b$, which postulated that efficacy would mediate between PBDI and SWL, could not be conclusively proven. This can be directly attributed to the fact that PBDI had a negative correlating relationship with SWL, which is highly enthralling and should be further explored.

\section{Limitations of the study and suggestions for future research}

According to Kamakura (2010), cross-sectional study designs can potentially lead to common-method bias. This crosssectional study could potentially significantly benefit from a longitudinal design, in which phenomena are studied over the course of the student's development as a first-year and also as a senior student. The population utilised in this study, albeit large and highly representative of the South African population was drawn from one province and one university. It could be beneficial to include all the universities in South Africa, across a number of provinces, to strengthen the validity of the research results. The most significant finding of this research, which will also set the basis for further research, was the fundamental difference between PBSU and PBDI in their properties and predicting qualities towards SWL. Highly intriguing was the fact that PBDI held a negative correlation with SWL, as directly opposed to PBSU which had a direct positive correlation with SWL. This warrants an in-depth future investigation, as it will shed light on the position of both PBSU and PBDI within the domain of positive psychology.

On a practical level, this study presents a clear value proposition for the utilisation of interventions to develop first-year students' capacity to proactively utilise their strengths as a means of achieving SWL, in particular. 
This can be done on an individual level, such as through student counselling, as well as on a group level, through interventions such as workshops, targeted to specific year groups of students. This will be particularly useful when combined with interventions that enable hope and efficacy amongst these students. Through these interventions, SWL can be effectively fostered amongst these first-year students who have to navigate their way in a complex and very new environment largely unbeknown to them, one in which they have to equip themselves to deal with a number of challenges. This will ask for a very concerted effort from university management to source, structure and implement these interventions, but will clearly hold significant value as SWL will directly lead to higher academic performance.

\section{Acknowledgements Competing interests}

The authors declare that they have no financial or personal relationships that may have inappropriately influenced them in writing this article.

\section{Authors' contributions}

F.W.S. (North-West University) was the research project leader, responsible for the administration of the project and acted as corresponding author on this work. E.D. (NorthWest University) and K.M. (North-West University) were involved as co-authors and subject matter experts. L.T.d.B. (North-West University) was a co-author and was responsible for the statistical analysis and reporting of this work.

\section{References}

Adams, V.H., Snyder, C.R., Rand, K.L., King, E.A., Sigman, D.R., \& Pulvers, K.M. (2002). Hope in the workplace. In R. Giacolone \& C. Jurkiewics (Eds.), Workplace spirituality and organization performance (pp. 367-377). New York, NY: Sharpe.

Alfonso, V.C., \& Allison, D.B. (1992). Further development of the extended satisfaction with life scale. Manuscript submitted for publication.

Bakker, A.B., Albrecht, S.L., \& Leiter, M.P. (2011). Key questions regarding work engagement. European Journal of Work and Organizational Psychology, 20, 4-28. http://dx.doi.org/10.1080/1359432X.2010.485352

Bandura, A. (1993). Perceived self-efficacy in cognitive development and functioning. Educational Psychologist, 28, 117-148. http://dx.doi.org/10.1207/ s15326985ep2802 3

Bandura, A. (1998). Self-efficacy: The exercise of control. New York, NY: Freeman.

Botha, C., \& Mostert, K. (2014). A structural model of job resources, organisational and individual strengths use and work engagement. SA Journal of Industrial Psychology/SA Tydskrif vir Bedryfsielkunde, 40(1), Art. \#1135, 11 pages. http:// Psychology/SA Tydskrif vir Bedryfsie
dx.doi.org/10.4102/sajip.v40i1.1135

Bowers, K.M., \& Lopez, S.J. (2010). Capitalizing on personal strengths in college. Journal of College and Character, 11(1), 1-11. http://dx.doi.org/10.2202/19401639.1011

Chemers, M., Hu, L., \& Garcia, B. (2001). Academic self-efficacy and first-year college student performance and adjustment. Journal of Educational Psychology, 93, 55-64. http://dx.doi.org/10.1037/0022-0663.93.1.55

Chen, S., Westman, M., \& Eden, D. (2009). Impact of enhanced resources on anticipatory stress and adjustment to new information technology: A fieldexperiement test of conservation of resources theory. Journal of Occupational Health Psychology, 14(3), 219-230. http://dx.doi.org/10.1037/a0015282

Cohen, J. (1988). Statistical power analysis for the behavioral sciences. (Rev. edn.) Orlando, FL: Academic Press. http://dx.doi.org/10.1002/bs.3830330104

Compton, W.C. (2005). An introduction to positive psychology. Belmont, CA: Wadsworth.

Crant, J.M. (2000). Proactive behavior in organizations. Journal of Management, 26, 435-462. http://dx.doi.org/10.1177/014920630002600304

Cravens, K.S., Oliver, E.G., \& Stewart, J.S. (2010). Can a positive approach to performance evaluation help accomplish goals? Business Horizons, 53, 269-279. http://dx.doi.org/10.1016/j.bushor.2009.09.005
Cropanzano, R., \& Wright, T.A. (2001). When a 'happy' worker is really a 'productive' worker: A review and further refinement of the happy-productive worker worker: A review and further refinement of the happy-productive worker
thesis. Practice and Research, 53(3), 182-199. http://dx.doi.org/10.1037/1061thesis. Practice

Curry, L.A., Snyder, C.R., Cook, D.L., Ruby, B.C., \& Rehm, M. (1997). The role of hope in academic and sport achievement. Journal of Personality and Social Psychology, 73, 1257-1267. http://dx.doi.org/10.1037/0022-3514.73.6.1257

Department of Higher Education and Training. (2013). White paper for post school education and training. Retrieved from http://www.dhet.gov.za

Diener, E. (1984). Subjective well-being. Psychological Bulletin, 95(3), 542-575.

Diener, E., Emmons, R.A., Larsen, R.J., \& Griffin, S. (1985). The satisfaction with life scale. Journal of Personality Assessment, 49, 71-75. http://dx.doi. org/10.1037/0033-2909.95.3.542

Dunn, T.J., Baguley, T., \& Brunsden, V. (2013). From alpha to omega: A practical solution to the pervasive problem of internal consistency estimation. British Journal of Psychology, 105(3), 399-412. http://dx.doi.org/10.1111/bjop.12046

Frederickson, B. (2002). Handbook of positive psychology. New York, NY: Oxford University Press.

Frese, M., \& Fay, D. (2001). Personal initiative: An active performance concept for the 21st century. Research in Organizational Behavior, 23, 133-187. http://dx.doi. org/10.1016/S0191-3085(01)23005-6

Gorgievski, M.J., \& Hobfoll, S.E. (2008). Work can burn us out or fire us up: Conservation of resources in burnout and engement. Handbook of stress and burnout in health care. The Netherlands: Nova Science.

Gupta, V., \& Singh, S. (2014). Psychological capital as a mediator of the relationship between leadership and creative performance behaviors: Empirical evidence from the Indian R\&D sector. The International Journal of Human Resource Management 25(10), 1373-1394. http://dx.doi.org/10.1080/09585192.2013.870311

Halama, P. (2010). Hope as a mediator between personality traits and life satisfaction. Studia Psychologica, 52(4), 309-314.

Hobfoll, S.E. (2002). Social and psychological resources and adaptation. Review of General Psychology, 6, 307-324. http://dx.doi.org/10.1037/1089-2680.6.4.307

Hobfoll, S.E., Freedy, J., Lane, C., \& Geller, P. (1990). Conservation of social resources: Social support resource theory. Journal of Social and Personal Relationships, 7 465-478. http://dx.doi.org/10.1177/0265407590074004

Hooper, D., Coughlan, J., \& Mullen, M. (2008). Structural equation modelling Guidelines for determining model fit. Electronic Journal of Business Research Methods, 6(1), 53-60.

Kaiser, R.B., \& White, R.P. (2009). Debunking an unbalanced approach to development. Leadership in Action, 28(5), 9-12.

Kamakura, W.A. (2010). Common methods bias. Wiley International Encyclopedia of Marketing. New York, NY: Wiley.

Larson, M., \& Luthans, F. (2006). The potential added value of psychological capital in predicting work attitudes. Journal of Leadership and Organization Studies, 13, 44-61. http://dx.doi.org/10.1177/10717919070130020601

Le Grange, L. (2011). (Re)thinking (trans)formation in South African (higher) education. Perspectives in Education, 29(2), 1-9.

Lightsey, J., Richard, O., Ervin, A., Benjamin, E., Gharghani, G., \& George, M.D. (2014). Generalized self-efficacy, positive cognitions, and negative cognition as mediators of the relationship between conscientiousness and meaning in life. Canadian Journal of Behavioural Science, 46(3), 436-445. http://dx.doi. org/10.1037/a0034022

Linley, P.A., Joseph, S., Harrington, S., \& Wood, A.M. (2006). Positive psychology: Past, present, and (possible) future. Journal of Positive Psychology, 1, 3-16. http:// dx.doi.org/10.1080/17439760500372796

Luthans, F., Avey, J.B., Avolio, B.J., \& Peterson, S.J. (2010). The development and resulting performance impact of positive psychological capital. Human Resource Development Quarterly, 21, 41-67. http://dx.doi.org/10.1002/hrdq.20034

Luthans, F., Avolio, B.J., Avey, J.B., \& Norman, S.M. (2007). Positive psychological capital: Measurement and relationship with performance and satisfaction. Persone Psychology, 60, 541-572. http://dx.doi.org/10.1111/j.1744-6570.2007.00083.x

Luthans, B.C., Luthans, K.W., \& Avey, J.B. (2013). Building the leaders of tomorrow: The development of academic psychological capital. Journal of Leadership \& Organizational Studies, 20, 1-9.

Luthans, F., Youssef, C.M., \& Avolio, B.J. (2007). Psychological capital. New York, NY: Oxford University Press.

Martin, A., \& Marsh, H. (2006). Academic resilience and its psychological and educational correlates: A construct validity approach. Psychology in the Schools, 43, 267-281. http://dx.doi.org/10.1002/pits.20149

Mouton, N., Louw, G.P., \& Strydom, G.L. (2013) Present-day dilemmas and challenges of the South African tertiary system. International Business \& Economics Research Journal, 12(13), 285-300.

Muthén, L.K., \& Muthén, B.O. (2014). Mplus user's guide (7th edn.). Los Angeles, CA: Muthén \& Muthén.

Petersen, I., Louw, J., \& Dumont, K. (2009). Adjustments to university and academic performance among disadvantaged students in South Africa. Educational Psychology, 29(1), 99-115. http://dx.doi.org/10.1080/01443410802521066

Peterson, S., \& Luthans, F. (2003). The positive impact and development of hopeful leaders. Leadership \& Organization Development Journal, 24(1), 26-31. http:// dx.doi.org/10.1108/01437730310457302

Peterson, C., \& Seligman, M.E.P. (2004). Character strengths and virtues: A handbook and classification. New York, NY: Oxford University Press. 
Reeve, K.L., Shumaker, C., Yearwood. E.L., Crowell, N.A., \& Riley, J.B. (2013). Perceived stress and social support in undergraduate nursing students' educational experiences. Nurse Education Today, 33(4), 419-424. http://dx.doi.org/10.1016/j. nedt.2012.11.009

Riolli, L., Savicki, V., \& Richards, J. (2012). Psychological capital as a buffer to student strengths. Psychology, 3(12), 1202-1207. http://dx.doi.org/10.4236/ psych.2012.312A178

Rode, J.C., Arthaud-Day, M.L., Mooney, C.H., Near, J.P., Baldwin, T.T., Bommer, W.H. et al. (2005). Life satisfaction and student performance. Academy of Management Learning \& Education, 4, 421-433. http://dx.doi.org/10.5465/ AMLE.2005.19086784

Rucker, D.D., Preacher, K.J., Tormala, Z.L., \& Petty, R.E. (2011). Mediation analysis in social psychology: Current practices and new recommendations. Social and Personality Psychology Compass, 5/6, 359-371. http://dx.doi.org/10.1111/ Personality Psychology
j.1751-9004.2011.00355.

Ruthig, J.C., Perry, R.P., Hall, N.C., \& Hladkyj, S. (2004). Optimism and attributional retraining: Longitudinal effects on academic achievement, test anxiety, and voluntary course withdrawal in college students. Journal of Applied Social Psychology, 34, 709-730. http://dx.doi.org/10.1111/j.1559-1816.2004. tb02566.x

Salanova, M., Schaufeli, W.B., Martínez, I., \& Bresó, E. (2009). How obstacles and facilitators predict academic performance: the mediating role of study burnout and engagement. Anxiety, Stress \& Coping, 1, 57-70.

Salkind, N.J. (2009). Exploring research. (7th edn.). Englewood Cliffs, NJ: Pearson Prentice.

Schaufeli, W.B., \& Bakker, A.B. (2004). Job demands, job resources and their relationship with burnout and engagement: A multi-sample study. Journal of Organizational Behavior, 25, 293-315. http://dx.doi.org/10.1002/job.248

Seligman, M.E.P. (2011). Flourish: A visionary new understanding of happiness and well-being. New York, NY: Free Press.

Seligman, M.E.P., \& Csikszentmihalyi, M. (2000). Positive psychology: An introduction American Psychologist, 55, 5-14. http://dx.doi.org/10.1037/0003-066X.55.1.5

Shaughnessy, J.J., Zechmeister, E.B., \& Zechmeister, J.S. (2009). Research methods in psychology (8th edn.). New York, NY: McGraw-Hill.

Singh, S., \& Mansi, J. (2009). Psychological capital as predictor of psychological wellbeing. Journal of the Indian Academy of Applied Psychology, 35, 233-238.

Siu, O.L., Bakker, A.B., \& Jiang, X. (2013). Psychological capital among university students: Relationships with study engagement and intrinsic motivation. Journal of Happiness Studies, 15, 979-994. http://dx.doi.org/10.1007/s10902013-9459-2

Snyder, C.R. (2000). Handbook of hope. San Diego, CA: Academic Press.

Snyder, C.R. (2002). Hope theory: Rainbows in the mind. Psychological Inquiry, 13, 249-275. http://dx.doi.org/10.1207/S15327965PLI1304_01

Snyder, C.R., Harris, C., \& Anderson, J.R. (1991). The will and the ways: Development and validation of an individual-differences measure of hope. Journal of Personality and Social Psychology, 60, 570-585. http://dx.doi.org/10.1037/0022 3514.60.4.570
Snyder, C.R., Lapointe, A.B., Crowson, J.J. Jr, \& Early, S. (1998). Preferences of high and low hope people for self referential input. Cognition and Emotion, 12, 807-823. http://dx.doi.org/10.1080/026999398379448

Stajkovic, A.D., \& Luthans, F. (1998). Social cognitive theory and self-efficacy: Going beyond traditional motivational and behavioral approaches. Organizationa Dynamics, 26, 62-74. http://dx.doi.org/10.1016/\$0090-2616(98)90006-7

Stander, F.W., \& Mostert, K. (2013). Assessing the organisational and individual strengths use and deficit improvement amongst sport coaches. SA Journal of Industrial Psychology/SA Tydskrif vir Bedryfsielkunde, 39(2), 1-13. http://dx.doi. org/10.4102/sajip.v39i2.1160

Steenkamp, L.P., Baard, R.S., \& Frick, B.L. (2009). Factors influencing success in firstyear accounting at a South African university: A comparison between lecturers' assumption and students' perceptions. South African Journal of Accounting Research, 23(1), 113-140.

Van de Schoot, R., Lugtig, P., \& Hox, J. (2012). A checklist for testing measurement invariance. European Journal of Developmental Psychology 9, 486-492. http:// dx.doi.org/10.1080/17405629.2012.686740

Van Den Heuvel, M., Demerouti, E., Schaufeli, W.B., \& Bakker, A.B. (2010). Personal resources and work engagement in the face of change. In J. Houdmont (Ed.), Occupational health psychology: European perspectives on research, education and practice, (Vol. 4, pp. 124-150). Nottingham: Nottingham University Press. http://dx.doi.org/10.1002/9780470661550.ch7

Van Woerkom, M., Mostert, K., Els, C., Rothmann, S. Jr., \& Bakker, A.B. (in press) Following a strength-based and deficiency-based approach: The development and psychometric properties of a new scale. Manuscript submitted for publication.

Van Zyl, L.E., \& Rothmann, S. (2012). Flourishing of students in a tertiary educational institution in South Africa. Journal of Psychology in Africa, 22(4), 593-599.

Vandeyar, S. (2010). Responses of South African teachers to the challenge of school integration. South African Journal of Education, 30(3), 343-359.

Wang, Y., Chang, Y., Fu, J., \& Wang, L. (2012). Work-family conflict and burnout among Chinese female nurses: The mediating effect of psychological capital. BMC Public Health, 12(915), 1-8. http://dx.doi.org/10.1186/1471-2458-12-915

Wood, A.M., Linley, P.A., Maltby, J., Kashdan, T.B., \& Hurling, R. (2011). Using personal and psychological strengths lead to increase in well-being over time: A longitudinal study and the development of the strengths use questionnaire. Personality and Individual Differences, 50, 15-20. http://dx.doi.org/10.1016/j.paid.2010.08.004

Xanthopoulou, D., Bakker, A.B., Demerouti, E., \& Schaufeli, W.B. (2008). Reciprocal relationships between job resources, personal resources and work engagement. Journal of Vocational Behaviour, 74, 235-244. http://dx.doi.org/10.1016/j. jvb.2008.11.003

Youssef, C.M., \& Luthans, F. (2007). Positive organizational behaviour in the workplace: The impact of hope, optimisms, and resiliency. Journal of Management, 33, 774-800. http://dx.doi.org/10.1177/0149206307305562

Zhao, X., Lynch, J.G., \& Chen, Q. (2010). Reconsidering Baron and Kenny: Myths and truths about mediation analysis. Journal of Consumer Research, 37(2), 197-206. http://dx.doi.org/10.1086/651257

Zimmerman, B.J. (1995). Self-efficacy and educational development. In A. Bandura (Ed.), Self-efficacy in changing societies (pp. 202-231). New York, NY: Cambridge University Press. http://dx.doi.org/10.1017/CBO9780511527692.009 